\title{
Analysis of Student Mastery Levels on Composite Material Subjects in South Aceh Polytechnic Mechanical Engineering Study Program
}

\author{
M. Anhar Pulungan ${ }^{1)}$, Sera Delta Tanjung ${ }^{2)}$ \\ 1) South Aceh Polytechnic Mechanical Engineering Study Program \\ Jl. Merdeka, Beach Reclamation Complex, Tapaktuan, 23751, South Aceh, Tel. 0656-323699 \\ 2) Technical Study Program in South Aceh Polytechnic format \\ Jl. Merdeka, Beach Reclamation Complex, Tapaktuan, 23751, South Aceh, Tel. 0656-323699 \\ Email: anhar.240205@gmail.com
}

ARTICLE INFO

Article history:

Accepted

Keywords:

Ana lysis level

Composite materials

types of errors

Mechanical Engineering

\section{ABSTRACT}

\begin{abstract}
Research is included into the type of descriptive study using quantitative and qualitative approaches. The research procedure includes stage 1) initial observation, 2) preparation, 3) implementation, 4) evaluation, and 5) final results. The subjects in this study were the second semester students of Mechanical Engineering Study Program, totaling 24 people. Data collection techniques used 1) test questions, 2) interviews, 3) documentation, and 4) field notes. Data analysis techniques mastery level of the material were analyzed using the percentage formula. Interview data were analyzed in stages 1) reducing data, 2) presenting data, and 3) summarizing data. Instrument documentation and field notes were analyzed narratively. The results of data analysis on the level of student mastery of composite material shows that the group of students in the category of mastery is very mastering (SM) 0 students $(0 \%)$, the category of mastery mastering (M) is 9 students $(23.68 \%)$, the category of mastery is less mastering (KM) 16 students $(42.11 \%)$, mastery category not mastered (TM) 13 students (34.21\%). Students who mastered the mastery-1 category were 15 students $(39.47 \%)$, who mastered the mastery-2 category by 22 students $(57.89 \%)$, who mastered the mastery-3 category by 9 students $(23.68 \%)$ and categories mastery-4 as many as 0 students $(0 \%)$. Interview results obtained by some students 'mistakes in mastering composite material courses, namely a) errors in the use of formulas or concept errors, b) errors in algebraic fraction operations, c) students' lack of attention to the tests conducted, d) errors in inputting parameter values, e) errors in the operation of exponential numbers, $\mathrm{f}$ ) errors in formulating problems in the form of formulas (mathematical modeling), and g) principle errors.
\end{abstract}

\section{Introduction}

\subsection{Background of the Problem}

Composite material course is one of the compulsory courses programmed by South Aceh Polytechnic mechanical engineering students. To understand the course there are several disciplines that must be known, such as the fields of physics, chemistry, mechanical engineering, and mathematics. Not all disciplines are understood by students, so they have an effect on student learning outcomes.

Based on the final grades of Mechanical Engineering Study Program students in South Aceh Polytechnic in composite material courses for the even semester 2017/2018 shows the graduation rate of students in these courses is still below 50\%. The results of observations by researchers during the course of the course obtained information that the material composite material courses is difficult. This happens because of the many disciplines contained in the composite material course. Mastery of concepts for composite material courses needs to be emphasized to students, so that the expected learning objectives can be achieved. According 
to Irawati, DR (2014) that mastery of concepts is the basis of mastering theoretical principles meaning that to be able to master the principles and theories must first be mastered the concepts that make up the principles and theories concerned.

Therefore, researchers are interested in conducting research on the analysis of student mastery levels on composite material courses in the South Aceh Polytechnic Mechanical Engineering Study Program.

\subsection{Problem Formulation}

The problems to be solved in this study are:

1) B How can be level of student mastery of the subjects in the composite material Mechanical Engineering Study Program Polytechnic South Aceh?

2) A ethnic -type fault anything done by the students in understanding the subject of composite materials?

3) What factors cause students to make mistakes in understanding composite material courses?

\subsection{Research Objectives} study are:

Based on the background and formulation of the problem described, the objectives of this

1) Determine the level of student mastery of composite material courses in the South Aceh Polytechnic Mechanical Engineering Study Program.

2) Identify ethnic -type fault anything done by the students in understanding the subject of composite materials.

3) Determine the factors that cause students to make mistakes in understanding composite material courses.

\section{Literature review}

\subsection{The Role of Educators}

The learning process and learning outcomes is most students are largely determined by the role and competence of educators. Competent teachers will be able to create an effective learning environment and will be better able to manage his class study results students at the optimum level. Educators can act as mediators and evaluators in the learning process.

As a mediator educators have sufficient knowledge and understanding of the educational media because educational media are a communication tool to make teaching and learning processes more effective. In one teaching and learning process the educator should be a good evaluator. All assessments will be answered through evaluation activities. In other words, the assessment needs to be done because the ratings educators can determine the success of achieving goals, mastery of all- students to the lesson, as well as the accuracy or effectiveness of teaching methods. Another purpose of such assessment is to determine the position of students in the class or group. With assessments, educators can decide a masterpiece of students belonging to the group of intelligent, moderate, less, or quite good in its class when compared with his friends.

\subsection{Strategies for Generating Student Achievement}

Teaching activities that occur in interaction between lecturers and students with teaching materials as an intermediary. Lecturers who create a good learning environment then the learning interests of students are met. Students are learning subjects who enter the atmosphere of learning created by lecturers. Therefore, lecturers with their teaching styles try to influence the learning styles and ways of students, with differences in teaching styles used by lecturers it will give birth to good teaching and learning activities.

\subsection{Understanding Learning Difficulties}

In learning we often encounter difficulties faced by students, both general difficulties and difficulties of the subject matter itself. Difficulties are not only caused by incorrect learning methods, but can also be caused by individual differences that lead to differences in behavior. The state of students or students cannot learn as they should, that is what is called learning 
difficulties. Mulyadi (2010) Learning difficulties have a broader understanding than the notions of "Learning disorder, learning disabilities, learning disfunction, under achiever and slow learner". Those who are classified as above, will experience learning difficulties which are marked by the obstacles in the learning process.

Students who have difficulty in learning are students who fail or fail to achieve certain goals. The achievement of good learning outcomes is the hope of all parties involved in the teaching and learning process. But that cannot always be realized properly. In reality, there are many students who show symptoms that they cannot achieve as expected. However, an educator or lecturer continues to try with all his strength and mind to prepare his teaching program well and systematically.

\subsection{Causes of Learning Difficulties}

According to Syah, Muhbbin (2012), in broad outline the factors causing learning difficulties consist of two types, namely: a) Student internal factors, namely things or circumstances that arise from within the students themselves, and b) Factors external, namely things or circumstances that come from outside the students themselves.

\subsection{Types of Learning Difficulties}

To carry out the diagnosis of learning difficulties learning activities must be taken several stages. These stages Warkitri et al (in Ismail, 2016) include: 1) Identifying students who are thought to have learning difficulties; 2) Localize learning difficulties; 3) Determine the factors causing learning difficulties; 4) Estimating alternative assistance; 5) Determine possible ways to overcome them; and 6) Follow up.

The types of learning difficulties according to Murtadlo, Ali (2013) are dyslexia, dyspraxia (sensory integration disorder), dyscalculia, dysgraphia, auditory processing disorder, visual processing disorder, and attention deficit disorder (ADD).

\subsection{Learning Achievements and Factors affecting them}

According to Alwi, Hasan (2005) that achievement is defined as things that have been achieved (done, done and so on). In relation to business learning, achievement means learning outcomes achieved by students after conducting learning activities at a certain time period. Student achievement is able to show changes in the field of knowledge / experience, skills, values and attitudes. It can be concluded that achievement is the result of effort that has been achieved by someone, while learning achievement is the result achieved by someone after carrying out learning activities within a certain period of time.

There are several factors that affect teaching and learning activities according to Ismail (2016), namely:

1) Internal factors that influence learning activities can be described in the following two aspects:

a) Physiological aspects; Namely the general condition of the body or muscle tension that marks the level of fitness of the body's organs and joints, can affect the spirit in following the lessons. b) Psychological aspects; In addition to physiological aspects psychological aspects can also affect the quantity and quality of student learning outcomes, such as intelligence, talent, interest and motivation.

2) External factors that influence learning activities including the social environment of schools such as teachers, administrative staff, and classmates can influence student enthusiasm for learning.

\subsection{Composite Material}

Composite material which is used as material for this research includes: a) stress and strain, b) elastic deformation, c) plastic deformation, d) tensile properties, and e) casting

\subsection{Level of Mastery}

The researcher determines four categories of mastery levels that students must understand, namely a) Mastery 1: able to determine the value of the Modulus elasticity of a material that has elastic 
deformation, b) Mastery 2: able to analyze and determine the value of stresses in shear loads, c) Mastery 3:

able to determine the percentage extension of a material, and d) Mastery 4: able to determine and deduce problems regarding the actual stress and strain on a material.

\subsection{Types and Factors Causing Error}

Abstract learning is a pattern of learning with abstract thinking techniques that aim to gain understanding and solutions that exist in given problems that are abstract. In the process of student learning it is often found that students make mistakes in solving problems. In this study, the authors define the notion of mistakes made by students, including student answers said to be wrong if:

a) The steps for solving the problem are not in accordance with the concept.

b) Problem solving is incomplete.

c) Problem solving is not available (not answered)

To clarify the analysis of student mastery in composite material subjects especially material the author determines the mistakes made by students according to those contained in mathematical characteristics, namely concept errors, principles, operations, and verbal errors.

The mistakes made by students in solving questions about composite materials must have causes. The cause of these errors can occur due to internal and external factors. The cause of errors due to internal factors can be in the form of under-average student understanding or intelligence. Students make mistakes both concepts, principles, operations, and verbal errors. The cause of student mistakes due to external factors can be in the form of situations and conditions at the time of the test, the situation and condition of the family, and the community.

\subsection{Previous Research} follows:

Some of the previous studies which have to do with the research to be carried out are as

a) Oroh, J (2013) Bahaw composite reinforcement materials without treatment and with alkali treatment as well as the percentage of volume fraction and the variation in the length of the fiber with straight fiber orientation have an influence on the composition of the mechanical properties of the composite.

b) Kurniawan, I (2014) concluded that increasing the reinforcement fraction will increase the distribution of $\mathrm{SiC}$ formed and the distribution is not homogeneous. The specific wear of the material decreases with increasing reinforcement fraction, meaning that the material is more resistant to abrasion or wear.

c) Hermayawati (2010) concluded that the various causes of student learning difficulties are as follows: a) There is no interest in learning, b) Interested in learning but basic knowledge is lacking; c) Motivation is good, ability is good, but the environment is not supportive, d) Motivation is quite good, but 'forgets' the basic concepts he has learned; and e) Learning motivation is high, but learning opportunities are too short.

\section{Research Method}

\subsection{Types and Research Approaches}

Research is included into the type of descriptive study using quantitative and qualitative approaches. The quantitative approach is used to determine the level of mastery of students in understanding composite material courses, while the qualitative approach is used to describe the types of errors and factors that cause errors made by students in understanding composite material courses.

\subsection{Research Procedure}

The procedures in this study include 5 stages, namely: a) initial observation, b) preparation stage , c) implementation phase , d) evaluation phase, and e) final results. The research procedures carried out can be seen in the fishbone below. 


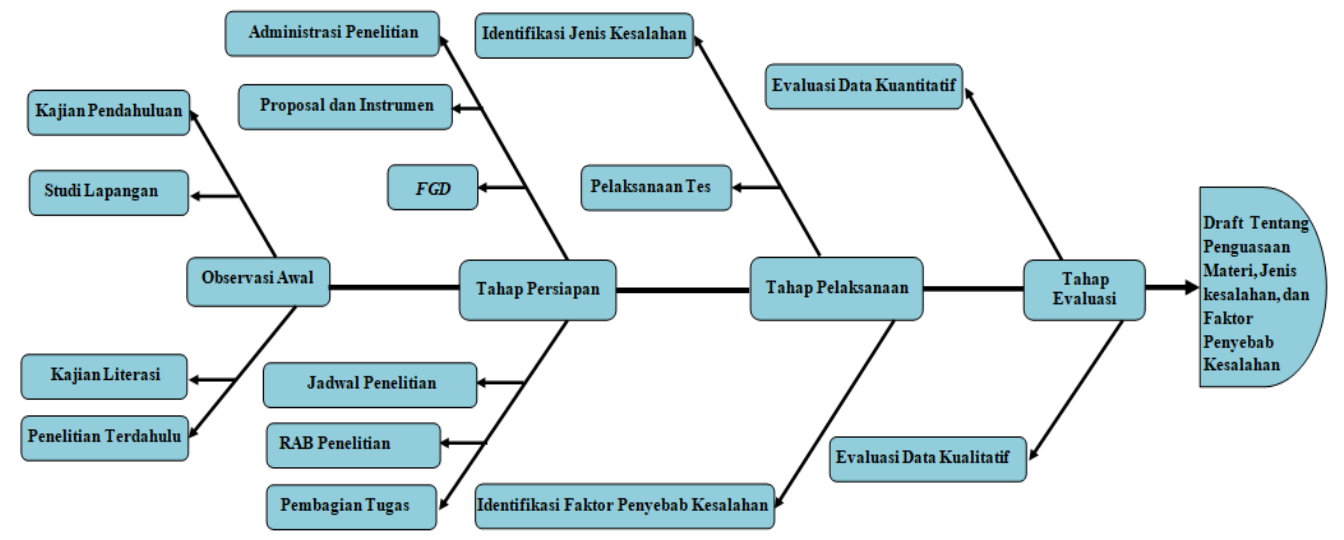

\subsection{Research Subjects}

Figure 1. Fishbone Research

As for the subjects in this study were 38 students in semester 2 of the Mechanical Engineering Study Program.

\subsection{Data Collection Techniques}

Data collection techniques used in this study include: a) material mastery test questions, b) interviews, c) documentation, and d) field notes.

\subsection{Data Analysis Techniques}

1. Analysis of Material Mastery Tests

Data analysis techniques for students' mastery level in understanding composite material courses were analyzed using percentage formulas.

Persentase tingkat penguasaan $(\mathrm{P})=\frac{\text { Frekuensi jawabanmahasi swe }}{\text { Tumlah mahasikwa }} \times 100 \%$

Information:

$\mathrm{P}=$ Percentage of mastery level

$\mathrm{f}=$ Frequency of student answers

$\mathrm{N}=$ Number of students

$100 \%=$ The theta number $\mathrm{p}$

Table 1. Mastery classification ISWA by Score

\begin{tabular}{ccc}
\hline No & Score in\% & $\begin{array}{c}\text { Provision } \\
\text { Classification }\end{array}$ \\
\hline 1 & $76-100$ & Expert \\
2 & $56-75$ & Dominate \\
3 & $41-55$ & Not Mastering \\
4 & $0-40$ & No Mastering \\
\hline
\end{tabular}

To determine the types of student errors in understanding composite material courses, researchers look at each answer answered by students.

2. Analysis of Interview Results

Interview data were analyzed with the following stages 1) reducing data, 2) presenting data, and 3) summarizing data.

3. Documentation and Field Notes

For instrument documentation and field notes are analyzed narratively, so that the data during the study is more detailed. 


\section{Results and Discussion}

\subsection{Mastery Student ISWA in Materials Composite Materials}

Based on the mastery test of composite material for 38 students of the Mechanical Engineering Study Program in South Aceh obtained the results as in Table 2 below.

Table 2. Test Material Mastery Score for Composite Material

\begin{tabular}{|c|c|c|c|c|c|c|c|c|c|c|c|c|}
\hline \multirow{2}{*}{ Student Code } & \multicolumn{10}{|c|}{ Composite Material Test Mastery Score on each Item } & \multirow{2}{*}{$\begin{array}{l}\text { Total } \\
\text { Score }\end{array}$} & \multirow{2}{*}{ Ket } \\
\hline & 1 & 2 & 3 & 4 & 5 & 6 & 7 & 8 & 9 & 10 & & \\
\hline 1803001 & 5 & 4 & 4 & 8 & $\overline{0}$ & 10 & 5 & $\overline{0}$ & 0 & $\overline{0}$ & 36 & $\mathrm{TM}$ \\
\hline 1803002 & 4 & 4 & 2 & 8 & 2 & 6 & 10 & 0 & 3 & 0 & 39 & $\mathrm{TM}$ \\
\hline 1803004 & 4 & 5 & 2 & 8 & 8 & 8 & 0 & 0 & 5 & 0 & 40 & TM \\
\hline 1803005 & 8 & 5 & 6 & 10 & 0 & 8 & 0 & 4 & 2 & 0 & 43 & $\mathrm{KM}$ \\
\hline 1803010 & 0 & 4 & 10 & 10 & 8 & 8 & 0 & 4 & 0 & 2 & 46 & $\mathrm{KM}$ \\
\hline 1803011 & 2 & 6 & 6 & 6 & 10 & 10 & 0 & 0 & 0 & 0 & 40 & TM \\
\hline 1803012 & 8 & 5 & 4 & 10 & 0 & 4 & 4 & 0 & 7 & 0 & 42 & $\mathrm{KM}$ \\
\hline 1803013 & 6 & 4 & 4 & 8 & 0 & 10 & 0 & 6 & 0 & 0 & 38 & $\mathrm{TM}$ \\
\hline 1803014 & 4 & 5 & 6 & 4 & 10 & 10 & 0 & 4 & 5 & 2 & 50 & $\mathrm{KM}$ \\
\hline 1803015 & 7 & 4 & 6 & 6 & 6 & 5 & 10 & 0 & 0 & 0 & 44 & $\mathrm{KM}$ \\
\hline 1803016 & 5 & 4 & 10 & 3 & 10 & 0 & 10 & 4 & 5 & 0 & 51 & KM \\
\hline 1803017 & 2 & 8 & 6 & 5 & 2 & 8 & 10 & 4 & 4 & 2 & 51 & $\mathrm{KM}$ \\
\hline 1803018 & 8 & 6 & 10 & 10 & $\overline{5}$ & 7 & 8 & 10 & 5 & $\overline{3}$ & 72 & $\bar{M}$ \\
\hline 1803019 & 6 & 0 & 8 & 10 & 10 & 2 & 10 & 0 & 2 & 0 & 48 & $\mathrm{KM}$ \\
\hline 1803020 & 0 & 5 & 10 & 5 & 8 & 10 & 0 & 4 & 4 & 0 & 46 & $\mathrm{KM}$ \\
\hline 1803021 & 4 & 4 & 4 & 10 & 0 & 10 & 0 & 2 & 2 & 6 & 42 & $\mathrm{KM}$ \\
\hline 1803022 & 4 & 4 & 10 & 5 & 0 & 10 & 6 & 4 & 2 & 0 & 45 & $\mathrm{KM}$ \\
\hline 1803023 & 4 & 6 & 8 & 10 & 2 & 0 & 10 & 4 & 6 & 6 & 56 & $\mathrm{M}$ \\
\hline 1803024 & 6 & 5 & 10 & 3 & 0 & 10 & 0 & 2 & 0 & $\overline{0}$ & 36 & $\mathrm{TM}$ \\
\hline 1803025 & 2 & 10 & 5 & 8 & 8 & 10 & 10 & 10 & 8 & 0 & 71 & $\mathrm{M}$ \\
\hline 1803026 & 4 & 8 & 8 & 2 & 0 & 8 & 0 & 4 & 2 & $\overline{0}$ & 36 & $\mathrm{TM}$ \\
\hline 1803027 & 10 & 5 & 8 & 8 & 10 & 10 & 0 & 4 & 0 & 0 & 55 & $\mathrm{KM}$ \\
\hline 1803028 & 9 & 4 & 10 & 10 & 2 & 10 & 4 & 10 & $\overline{4}$ & $\overline{0}$ & 63 & $\mathrm{M}$ \\
\hline 1803029 & 6 & 6 & 4 & 10 & 10 & 10 & 10 & 5 & 2 & 0 & 63 & M \\
\hline 1803030 & 6 & 5 & 10 & 10 & 0 & 4 & 2 & 0 & 4 & 0 & 41 & $\mathrm{KM}$ \\
\hline 1803031 & 2 & 4 & 5 & 5 & 10 & 0 & 0 & 4 & 0 & $\overline{0}$ & 30 & TM \\
\hline 1803032 & 10 & 4 & 10 & 6 & $\overline{8}$ & 4 & 4 & $\overline{3}$ & 4 & $\overline{4}$ & 57 & $\mathrm{M}$ \\
\hline 1803033 & 6 & 4 & 10 & 10 & 10 & 8 & 8 & 0 & 7 & 8 & 71 & M \\
\hline 1803034 & 4 & 10 & 5 & 2 & 10 & 10 & 10 & 0 & 2 & 0 & 53 & $\mathrm{KM}$ \\
\hline 1803035 & 6 & 6 & 10 & 6 & 10 & 10 & 3 & 8 & 4 & 4 & 67 & $\mathrm{M}$ \\
\hline 1803036 & 8 & 2 & 10 & 10 & 2 & 2 & 0 & 0 & 0 & 0 & 34 & $\mathrm{TM}$ \\
\hline 1803037 & 4 & 4 & 9 & 3 & 0 & 0 & 0 & 0 & 0 & 0 & 20 & TM \\
\hline 1803038 & 4 & 4 & 10 & 5 & 2 & 0 & 0 & 2 & 0 & 0 & 27 & $\mathrm{TM}$ \\
\hline 1803039 & 10 & 5 & 11 & 10 & 0 & 3 & 6 & 7 & 5 & 3 & 60 & $\mathrm{M}$ \\
\hline 1803040 & 8 & 0 & 8 & 5 & 2 & 2 & 0 & 0 & 0 & 0 & 25 & $\mathrm{TM}$ \\
\hline 1803041 & 10 & 5 & 10 & 5 & 0 & 0 & 0 & 0 & 6 & 0 & 36 & $\mathrm{TM}$ \\
\hline 1803042 & 4 & 4 & 10 & 4 & 0 & 0 & 4 & 0 & 4 & 0 & 30 & TM \\
\hline 1803044 & 8 & 5 & 5 & 2 & 0 & 0 & 0 & 2 & 0 & 0 & 22 & $\mathrm{TM}$ \\
\hline
\end{tabular}

Information:

\footnotetext{
$\mathrm{M}=$ Mastering

$\mathrm{KM}=$ Not mastered

$\mathrm{TM}=$ Not mastered
} 
Based on Table 2 it can be noted that the minimum and maximum values obtained by students are 20 and 72 , respectively. The average score of the mastery test results of the composite material is 45.42 , while the ideal score is 100 . The test results can also be distinguished from the level of mastery students in understanding composite material. The student group for the mastery category is very mastering (SM) 0 students $(0 \%)$, the mastery category is mastering (M) 9 students $(23.68 \%)$, the mastery category is less mastering (KM) 16 students $(42.11 \%)$, the satisfaction category did not master (TM) 13 students (34.21\%).

\subsection{Distribution of Student Mastery in Understanding Composite Material Materials}

Based on Table 2 above, student mastery can be distributed in understanding composite material. The distribution of student mastery can be seen in Table 3 below.

Table 3. Distribution of Student Provisions about Composite Material Materials

\begin{tabular}{|c|c|c|c|c|c|}
\hline No & Student Code & Mastery-1 & Mastery-2 & Mastery-3 & Mastery-4 \\
\hline 1 & 1803001 & - & - & - & - \\
\hline 2 & 1803002 & - & - & - & - \\
\hline 3 & 1803004 & - & - & - & - \\
\hline 4 & 1803005 & $\sqrt{ }$ & - & - & - \\
\hline 5 & 1803010 & - & $\sqrt{ }$ & - & - \\
\hline 6 & 1803011 & - & $\sqrt{ }$ & - & - \\
\hline 7 & 1803012 & $\sqrt{ }$ & - & - & - \\
\hline 8 & 1803013 & - & - & - & - \\
\hline 9 & 1803014 & - & $\sqrt{ }$ & - & - \\
\hline 10 & 1803015 & - & $\sqrt{ }$ & - & - \\
\hline 11 & 1803016 & - & $\sqrt{ }$ & - & - \\
\hline 12 & 1803017 & - & - & $\sqrt{ }$ & - \\
\hline 13 & 1803018 & $\sqrt{ }$ & $\sqrt{ }$ & $\sqrt{ }$ & - \\
\hline 14 & 1803019 & - & $\sqrt{ }$ & - & - \\
\hline 15 & 1803020 & - & $\sqrt{ }$ & - & - \\
\hline 16 & 1803021 & - & - & - & - \\
\hline 17 & 1803022 & - & - & $\sqrt{ }$ & - \\
\hline 18 & 1803023 & - & $\sqrt{ }$ & - & - \\
\hline 19 & 1803024 & - & - & - & - \\
\hline 20 & 1803025 & $\sqrt{ }$ & $\sqrt{ }$ & $\sqrt{ }$ & - \\
\hline 21 & 1803026 & $\sqrt{ }$ & - & - & - \\
\hline 22 & 1803027 & $\sqrt{ }$ & $\sqrt{ }$ & - & - \\
\hline 23 & 1803028 & $\sqrt{ }$ & $\sqrt{ }$ & $\sqrt{ }$ & - \\
\hline 24 & 1803029 & $\sqrt{ }$ & $\sqrt{ }$ & $\sqrt{ }$ & - \\
\hline 25 & 1803030 & - & $\sqrt{ }$ & - & - \\
\hline 26 & 1803031 & $\sqrt{ }$ & $\sqrt{ }$ & - & - \\
\hline 27 & 1803032 & $\sqrt{ }$ & $\sqrt{ }$ & - & - \\
\hline 28 & 1803033 & - & $\sqrt{ }$ & - & - \\
\hline 29 & 1803034 & $\sqrt{ }$ & $\sqrt{ }$ & $\sqrt{ }$ & - \\
\hline 30 & 1803035 & $\sqrt{ }$ & $\sqrt{ }$ & $\sqrt{ }$ & - \\
\hline 31 & 1803036 & - & $\sqrt{ }$ & - & - \\
\hline 32 & 1803037 & - & - & - & - \\
\hline 33 & 1803038 & - & $\sqrt{ }$ & - & - \\
\hline 34 & 1803039 & $\sqrt{ }$ & $\sqrt{ }$ & $\sqrt{ }$ & - \\
\hline 35 & 1803040 & - & - & - & - \\
\hline
\end{tabular}




\begin{tabular}{|c|c|c|c|c|c|}
\hline No & Student Code & Mastery-1 & Mastery-2 & Mastery-3 & Mastery-4 \\
\hline 36 & 1803041 & $\sqrt{ }$ & - & - & - \\
\hline 37 & 1803042 & - & - & - & - \\
\hline 38 & 1803044 & $\sqrt{ }$ & - & - & - \\
\hline & total & 15 & 22 & 9 & 0 \\
\hline \multicolumn{2}{r|}{ Percent } & $39.47 \%$ & $57.89 \%$ & $23.68 \%$ & $0 \%$ \\
\hline
\end{tabular}

From Table 3 a percentage of student mastery levels is obtained for each mastery. Students who mastered the mastery-1 category were 15 students $(39.47 \%)$, who mastered the mastery- 2 category by 22 students $(57.89 \%)$, who mastered the mastery -3 category by 9 students $(23.68 \%)$ and categories mastery- 4 as many as 0 students $(0 \%)$. Of the four categories of authority, the ruling category 4 is not controlled at all.

\subsection{Interview Results}

Interview results obtained by some students 'mistakes in mastering composite material courses, namely a) errors in the use of formulas or concept errors, b) errors in algebraic fraction operations, c) students' lack of attention to the tests conducted, d) errors in inputting parameter values, e) errors in the operation of exponential numbers, f) errors in formulating problems in the form of formulas (mathematical modeling), and $\mathrm{g}$ ) principle errors.

\section{Conclusion and Suggestions \\ 5.1 Conclusions}

Based on the data processing, it can be concluded that:

1. The student group for the mastery category is very mastering (SM) 0 students $(0 \%)$, the mastery category (M) is 9 students $(23.68 \%)$, the mastery category is less mastering (KM) 16 students $(42.11 \%)$, the mastery category not mastered (TM) 13 students $(34.21 \%)$.

2. Students who mastered the mastery-1 category were 15 students $(39.47 \%)$, who mastered the mastery- 2 category by 22 students $(57.89 \%)$, who mastered the mastery- 3 category by 9 students $(23.68 \%)$ and categories mastery-4 as many as 0 students $(0 \%)$.

3. Interview results obtained by some students 'mistakes in mastering composite material courses, namely a) errors in the use of formulas or concept errors, b) errors in algebraic fraction operations, c) students' lack of attention to the tests conducted, d) errors in inputting parameter values, e) errors in the operation of exponential numbers, $f$ ) errors in formulating problems in the form of formulas (mathematical modeling), and g) principle errors.

\subsection{Suggestions}

Based on the conclusion above, it is known that mastery categories 3 and 4 are difficult to be mastered by students, so it is recommended for lecturers supporting composite material courses to be more serious in teaching these materials so that student learning outcomes can be improved.

\section{THANK-YOU NOTE}

Our gratitude goes to the Republic of Indonesia Ministry of Research, Technology and Higher Education for providing research funds to train researchers in developing science, especially in the field of mechanical engineering education. In addition, the researchers also expressed their gratitude to LLDikti Region XIII Aceh for facilitating the researchers in completing this research. Furthermore, we would also like to thank the academicians of the South Aceh Polytechnic who have provided a lot of assistance in completing this research.

\section{References}

[1] Alwi, Hasan et al. 2005. Big Indonesian Dictionary. Jakarta: Library.

[2] Hermayawati. 2010. Analysis of Student English Learning Difficulties. Journal of Socio-Humanities Vol.1 No. September 1, 2010, ISSN: 2087-1899. English Education Study Program, FKIP UMBY. 
[3] Irawati, DR. 2014. Analysis of the Mastery of Physics Concepts in the Subjects of Large and Class X State Senior High School 1 Sale Rembang. Thesis: Faculty of Mathematics and Natural Sciences Semarang State University.

[4] Mulyadi. 2010. Diagnosis of Learning Difficulties \& Guidance against Special Learning Difficulties. Yogyakarta: Nuha Litera.

[5] Murtadlo, Ali. 2013. Difficult Learning (Learning Difficult) in Mathematics Learning. Journal of Difficulties, 2013, 7. Purwoko, et al. 2009. Integrated Science Class VIII Middle School. Jakarta: Yudhistira.

[6] Shah, Muhbbin. 2012. Psychology of Learning. Jakarta: PT. Raja Grafindo Persada.

[7] Syahputra, Eddie. 2012. The Effect of Using Archored Instruction Learning Models on Improving Students' Mathematical Communication Skills and Self-Concepts. Thesis. Bandung: Indonesian Education University.

[8] Sugiyono (2012). Statistics for Research. Bandung: Alfabeta. Ismail. 2016. Diagnosis of Student Learning Difficulties in Active Learning in Schools. Journal of Education, Vol 2, Number 1, January 2016, ISSN: 2460-4917. Banda Aceh.

[9] Zuldafrial, and Muhammad Born. 2012. Qualitative Research. Surakarta: Yuma Reader: 162. 